\title{
Vaginal Tablet Dosage Form
}

National Cancer Institute

\section{Source}

National Cancer Institute. Vaginal Tablet Dosage Form. NCI Thesaurus. Code C69049.

A tablet intended for vaginal administration. 